\title{
“TONALISM": NAME, SOUL, DESTINY AND IDENTITY DETERMINED BY THE 260-DAY CALENDER IN MESOAMERICA
}

\author{
LARS KIRKHUSMO PHARO \\ Harvard University
}

\section{A B S TRACT}

In various Mesoamerican cultures, i.e. civilisations of Middle America, a calendar name is part of the antroponym. Besides having conventional personal names, both human beings and deities carry day-names from the 260-day calendar. In addition, world ages or world periods, periods of the traditional 365-day calendar and the 52-year calendar as well as the cardinal directions of the quadripartite world were categorised by day-names of the 260day calendar. Thus not only human and divine beings but also space and time received designations from this calendar. Moreover, this onomastic practice of giving personal names from day signs of the 260-day calendar called "tonalism" (from Nahuatl) - is related to the Mesoamerican concepts of destiny and to what is known in history of religions as the "freesoul". Consequently, this anthropnymic tradition provides identity to human, divine beings and spatial-temporal phenomena.

\section{[1] INTRODUCTION}

In various Mesoamerican cultures, antroponyms ${ }^{1}$ consists of calendar names. Mesoamerica has been defined as a cultural-geographical region including the northwestern, central and southern Mexico, Guatemala, Belize, and the western part of Honduras and El Salvador. In this area peoples - like the Aztecs, Olmecs, Zapotecs, Toltecs, Tlapanecs, Teotihuacanos, Tarascas, Otomís, Mixtecs, Maya etc. - lived in urban civilisations c. 1000 B.C. - 1521 A.D. Contacts existed between the different communities through migrations, pilgrimage, trade, diplomacy, war and conquest. Despite their particular traditions and languages, the numerous groups of people of Mesoamerica have several cultural and religious traits in common. Notwithstanding the Spanish conquest at the beginning of the $16^{\text {th }}$ century, the languages, religions and cultures of millions of indigenous Mesoamerican peoples persist today.

[1] For antroponymic practises among the Nahua see Lockhart (1992, 117-130); among the Mixtecs (cf. Terraciano 2001, 150-157); among the Maya (see Roys 1940; Colas 2004). 
Besides having conventional personal names, both human beings and deities carry day names from the 260-day calendar - names, which have no relation to lineage or family or signify socio-political status. Manuscripts of the pre-Columbian period contain many examples of where an individual being is identified by his/her calendar name, represented by a logogram. Even world ages or world periods, the traditional 365-day calendar and the 52-year calendar as well as the quadripartite cardinal directions of the world had designations from one of the days of the 260day calendar.

This naming practice is heavily linked to "identity". How can the concept "identity" be defined? Otto Krogseth has suggested three general characteristics:

(i) Continuity in time vs. change. A quality, condition or nature of absolute or essential sameness.

(ii) A coherence where some fundamental aspects coordinate the person's or object's roles and functions.

(iii) Individuality or personality. A person or an object comprises in itself, in substance or in selfhood, a specific character - and not something else. He, she or it holds a certain distinctiveness or uniqueness as compared to other beings and objects (Krogseth 1992, 100-103).

The day signs of the 260-day calendar naming human beings, deities, world ages or world periods provide the named entity a predestined fate. In addition, human beings obtain a substance - what historians of religions call a "freesoul" (a freesoul is a substance, which can leave the body during the lifetime of a being) - connected to the day of their birth according to the 260-day calendar. The phenomenon of name giving by use of the 260-day calendar is called "tonalism" (Nahuatl, tonalli).

In general, the name stays with the individual or phenomenon throughout their existence. It is accordingly intimately connected to and operates as a determinative factor of how the carrier or the name is perceived. This is even more emphasised when the concept of the calendar name is closely associated with destiny and a soul. Predestination and the soul constitute continuity, coherence, individuality, personality and uniqueness. As a consequence, the calendar name, which in itself is marker of exceptionality, conveys essential identity features.

\section{[2] CALENDAR NAMES FROM THE 260-DAY DIVINATORY CALENDAR}

Mesoamerican cultures shared a 260-day and a 365-day calendar, which together form a 52-year cycle called a Calendar Round. The traditional 260-day calendar and the 365-day calendar ${ }^{2}$ are still used in various parts of Mesoamerica today.

[2] The temporal structure of the Mesoamerican 365-day calendar was, however, modified to the Catholic European liturgical 365-day calendar after the Spanish invasion. 
They are employed by indigenous peoples in the highlands of Guatemala and in the states of Veracruz, Chiapas and Oaxaca, Mexico. ${ }^{3}$ The custom of naming people after day signs of this calendar has, however, gone out of practice in many cultures.But the Mixe of Oaxaca, Mexico applies the names, but probably not the numbers (Søren Wichmann, personal communication, 2007). Today people get names from Patron Saints, which is also based upon the calendar (albeit the 365day calendar) since every day of the Catholic calendar is associated with a saint.

The 260-day calendar consists of twenty day-names (sp. "veintena") together with thirteen days with a coefficient (sp. "trecena"). Twenty twenty day-units multiplied with thirteen amounts to 260 days. ${ }^{4}$ The calendar had local names in the different languages in Mesoamerica but their meanings could be the same (Taube 1988, 180).

The sources of information about the Mesoamerican calendars and to the naming practices vary. Such sources include indigenous iconography, narrative visual sequential systems and logosyllabic (i.e. writing) inscriptions ${ }^{5}$, indigenous colonial accounts, descriptions by Spanish ethnographer missionaries of the colonial period and modern ethnography.

[3] In particular among the Mixe, but fundamental components persists among the Zapotecs, Chatinos, Mazatecs, Chinantecs and Mixtecs of Southern Mexico whereas in the highlands of Guatemala the calendar is used by the K'iche' but is also known by the Ixil, Akateko, Q'anjob'al, Mam, Popti and Chuj. Cf. the research project (and webpage) "Time and Identity" under the direction of Professor Dr. Maarten E.R.G.N. Jansen at Leiden University (http: //www . archaeology . leiden. edu/research/ ancient-america/mexico/time-identity/).

[4] Using names from a Maya language as an example, Sir Eric Thompson has summed up the mathematical foundation of this system as follows: 'Since 13 and 20 have no common factor, it is obvious that the same combination of name and number will not recur until 260 days have elapsed. At each repetition of any name the attached number will be seven greater provided the sum is not in excess of 13; if the sum is greater than 13; that number has to be subtracted from it. The first day of the cycle was 1 Imix; accordingly, 20 days later Imix will repeat, but this time with the number 8 attached. At its next appearance the attached number will be $2(8+7=15 ; 15-13=2)$, so that the sequence of numbers attached to a given day name will run 1,8,2,9,3,10,4,11,5,12,6,13,7' (Thompson 1978, 67).

[5] Interestingly there are not many examples of personal names from the 260-day calendar represented in the Maya and epi-Olmec inscriptions, whereas they abound in inscriptions of the Nahuas, Zapotecs and Mixtecs. 
[3] THE NAMING CEREMONY AND SACRED VOCABULARY: DESTINY AND IDENTITY IN THE SELECTED DAY-NAME OF THE CALENDAR

The 260-day calendar had many functions but is first and foremost recognised in its application as a divinatory calendar. ${ }^{6}$

The Spanish ethnographer missionaries of the $16^{\text {th }}$ century assert that the Aztecs $^{7}$ employed the 260-day calendar (tonalamatl) as a divinatory in order to interpret the horoscope of a newborn child. This was executed with the purpose of giving the child its name and its "suerte" ("fate"; "destiny").

In his encyclopedic work about the Aztecs, The Florentine Codex, The Franciscan friar Bernardino de Sahagún (1499? -1590) outline in detail, in Nahuatl, a ceremony conducted at the time of a birth of a child where it was given its tonalli or calendar name. This is the day sign that was to predetermine the individual's destiny. The religious specialist, who held the necessary knowledge and training to practice this calendar, was designated as tonalpouhqui ("the one who is dedicated to the tonalli"). It was the tonalpouhque (Sahagún 1950-1982, 1957: Appendix to IV: 142) who found the sign the child was born under in order to identify its destiny in

[6] Why did people of Mesoamerica choose a cycle of 260 days for organising and systematising time within a calendar? Barbara Tedlock recapitulates some of the hypotheses that have been put forward by various scholars as follows:

(i) The cycle was construed by a permutation of 13 and 20 since both are cardinal coefficients in Mesoamerica.

(ii) The 260-calendar was applied to record observations of and to correlate various planetary cycles. The 260-day period is the interval between zenith transits of the sun near the latitude 15 north.

(iii) A double of 260-days (520 days) is equal to three eclipses half-years.

(iv) 260 days correspond to nine lunations; each consisting of slightly less than 29 days or the same number of months a woman is pregnant (Tedlock 1992, 93). Calendar specialists employed tables of the 260-day calendar in the Post-Classic Yucatec codices as almanacs. The 260-day period is close to the agricultural calendar in Mesoamerica (Milbrath 1999, 2; 12-15). Cf. Helga Larsen about ancient Copan (Larsen 1936). Milbrath deduce from this that the 260-day agricultural cycle and the cycle of human gestation were originally combined together (Milbrath 1999, 2). The 260-day cycle comprise agricultural rituals in Pre-Columbian Mesoamerica (Broda 1969, 52-54; Bricker \& Miram 2002, 40-41). The 260-calendar is utilised as an agricultural calendar by the contemporary Ch'orti' (Girard 1960, 304-305; Girard 1962, 328-342) and by the Mopan of San Antonio in Belize (Thompson 1930, 41). The growth cycle of one of the corn plants in Guatemala is, according to Dennis Tedlock, 260 days. Thus, the K'iche' calendar specialist, Aj Q'in, call the 260-day calendar for 'the calendar of the earth' to distinguish it from the astronomic intervals like the year of the sun (Tedlock 1992, 206). Cf. also Barbara Tedlock (Tedlock 1992, 204-205).

[7] The Aztecs or Mexica as they called themselves was originally, in their own self-portrayls, a Nahuatlspeaking nomadic tribe. They founded the city of Tenochtitlan, today Mexico City, which became the capital of their short-lived empire in the northern and central part of Mexico from 1345 A.D. to 1521 A.D. The term "Aztec" derives from aztecatl,"person from Aztlán". Aztlán, which can be paraphrased as "the white place" or "the place of the herons" in Nahuatl, was the designation for their mythological place of origin. The name "Mexica" was given to the Aztecs by their patron deity, Huitzilopochtli, during their migration from Aztlán. 
the tonalamatl (Sahagún 1950-1982, 1957: IV, 111-115; Sahagún 1950-1982, 1969: VI: 197-198). The manuscript that contained the tonalpohualli, i.e. the 260-day count, was named tonalamatl ("the book of tonalli") in Nahuatl. The Dominican friar Diego Duran (1533 - 1588) writes:

"Thus, when a boy or a girl was born, the father or relatives of the baby immediately went to visit the astrologers, sorceres, or soothsayers, who were plentiful, begging them to state the destiny of the newborn boy or girl. The inquirer always carried with him offerings of food and drink. The astrologer and sorcererfortuneteller brought out the Book of the Horoscope, together with the calendar. Once the character of the day had been seen, prophecies were uttered, lots were cast, and a propitious or evil fate for the baby was determined by the consultation of a paper painted with all the gods they adored, each idol drawn in the square reserved for him" (Durán 1971, 398).

As noted, each individual received a tonalli from the calendar (tonalpohualli) that was decided by the calendar experts, tonalpouhque, according to the calendar sign he or she was born under. Hence, beside his/her ordinary name human beings and deities could be called for instance Ome Ehecatl (2 Ehecatl), Naui Ehecatl (4 Ehecatl), or Ce Atl (1 Atl), etc. of 260 possible day-names from the following list $^{8}$ :

[3.1] The 260-calendar day names (tonalpohualli) in Nahuatl

(i) Ce Cipactli (1 Alligator)

(ii) Ome Ehecatl (2 Wind).

(iii) Yei Calli (3 House)

(iv) Naui Cuetzpallin (4 Lizard).

(v) Macuilli Coatl (5 Serpent).

(vi) Chicuace Miquitztli (6 Death).

(vii) Chicome Mazatl (7 Deer).

(viii) Chicuei Tochtli (8 Rabbit).

(ix) Chicunaui Atl (9 Water).

(x) Matlactli Itzcuintli (10 Dog).

(xi) Matlactli once Ozomatli (11 Monkey).

[8] Note that only the, for the calendar names, relevant 13 numbers are translated into an indigenous language. 
(xii) Matlactli omome Malinalli (12 Grass).

(xiii) Matlactli omei Acatl (13 Reed).

(xiv) Ocelotl (Jaguar).

(xv) Cuautli (Eagle).

(xvi) Cozcaquautli (Vulture).

(xvii) Ollin (Movement).

(xviii) Tecpatl (Flint).

(xix) Quiauitl (Rain).

(xx) Xochitl (Flower).

TheTonalli was originally given to man by the dual deity (the masculine) Ometecuhtli and (the feminine) Omecihuatli according to the informants of Sahagúns in Códice Matritense from Real Academía de Historia (López 1988, 208). ${ }^{9}$ The day-name and soul was accordingly a sacred gift from the deities. The twenty day-names were associated with natural phenomena but had each a supernatural patron.

In Mixtec manuscripts the signs and numeral coefficients correspond to Nahuatl. It is intriguing that the Mixtecs of Oaxaca ${ }^{10}$, Mexico employed a sacred language - various versions are known from the different dialects - for the day signs and day numbers in their codices. Also the Mixe had an extraordinary vocabulary for the elements of their calendar (Smith 1973, 23-27; Lipp 1983, 203; Boone $2000,4)$. In Nahuatl the day (or year) One Reed is rendered as Ce Acatl in the common vocabulary. The Mixtec did not employ the colloquial Een Doo but Ca Huiyo (Dahlgren 1954, 282-287; Smith 1973, 23-27; Boone 2000, 4).

\section{[3.2] The Mixtec 260-day calendar}

Here is an example of signs of calendar names from the 260-day calendar in an illustration from the Mixtec $^{11}$ (Ñu Savi)-manuscript Codex Zouche-Nuttall(aka by the Mixtec name Códice Tonindeyeaccording to the suggestion by Gabina Aurora

[9] "Because there on the twelfth level he lives, there lives the true god. And (in his form of) partner (masculine) Ilhuicateotl has the name Ometecuhtli; and his mate (feminine) is called Omecihuatl, Ilhuicacihuatl. This means they govern the twelve (levels), they rule over the heavens. They say that we men are created there, that our tonalli comes from there when it comes to rest (the infant in the mother's womb), when there the infant falls in a drop. From there comes his tonalli, it penetrates inside him; Ometecuhtli sends it" (López 1988, 208).

[10] The Mixtecs call themselves Nuu Savi, "people of the rain" or "the people belonging to the rain god”,'Mixtec', which derives from Nahuatl Mixtecatl, means “Cloud People” (Whitecotton 1977, 23).

[11] Mixtec is a tonal language with high, mid and low tones, which probably explains the appearent identical words for different numerical coefficents (Smith 1973, 26). 


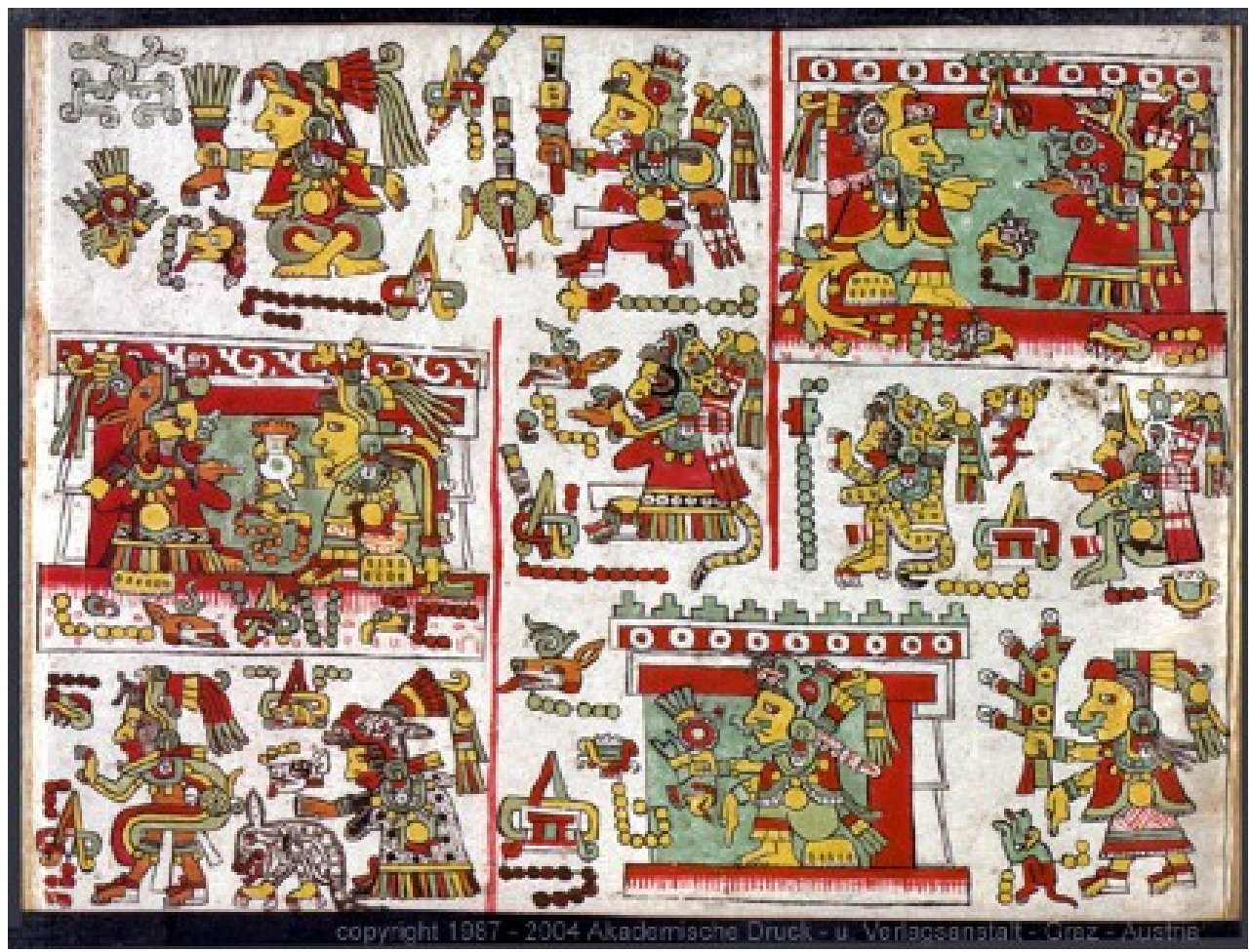

FIGURE 1: Códice Zouche-Nuttall (page 27) (British Museum ADD.MSS 39671) 
Normal Vocabulary (Alvarado Dictionary)

$\begin{array}{ll}1 & \text { Ee coo yechi } \\ 2 & \text { Vvui tachi } \\ 3 & \text { Uni huahi } \\ 4 & \text { Qmi, cumi (ti) yechi } \\ 5 & \text { Hoho coo } \\ 6 & \text { Iño ndeye, sihi } \\ 7 & \text { Usa idzu, sacuaa } \\ 8 & \text { Una idzo } \\ 9 & \text { Ee nduta } \\ 10 & \text { Usi ina } \\ 11 & \text { Usi ee codzo } \\ 12 & \text { Usi vvui yucu } \\ 13 & \text { Usi uni ndoo } \\ 14 & \text { Cuiñe } \\ 15 & \text { Yaha } \\ 16 & \text { (ti)sii } \\ 17 & \text { tnaa, nehe } \\ 18 & \text { Yuchi } \\ 19 & \text { Dzavui } \\ 20 & \text { Ita }\end{array}$

Special Day-Sign Vocabular ca, co quevui (1 Alligator). $\mathrm{ca}, \mathrm{co}, \mathrm{cu}$ chi (2 Wind). co cuau; mau (3 House). qui q(ue) (4 Lizard). q yo (5 Serpent). ñu na mahu(a) (6 Death). sa cuaa (7 Deer). na sayu (8 Rabbit). q tuta (9 Water). si hua (10 Dog). si i ñuu (11 Monkey). ca cuañe (12 Grass). si huiyo (13 Reed). huidzu (Jaguar). sa (Eagle). cuii (Vulture). qhi (Movement). cusi (Flint). co (Rain). huaco (Flower).

FIGURE 2: (Dahlgren 1954, 282-287; Smith 1973, 23-27)

Pérez Jiménz and Maarten Jansen). Cf. the illustration to the far left in the middle for described scene. From the left we see Lord Eight Deer (Mixtec calendar name: Naa Cuaa) Jaguar Claw and Lady Thirteen Snake (Mixtec calendar name: Si Yo) Flowering Snake, portrayed in a wedding scene. The bowl of chocolate, which Lady Thirteen Snake offer Lord Eight Deer represent the wedding. The signs of the calendar name and personal name to Lord Eight Deer is illustrated under his seat. The signs of the calendar name to Lady Thirteen Snake are located in front of her. The headdress represents her personal name. The ceremony was celebrated in the year Thirteen Reed (1031 AD) on the day Twelve Snake, which is indicated by the signs placed down in the middle from left to right.

Consequently, Lord Eight Deer would be named Naa Cuaa after the day of the 260-day calendar he was born and not by the conventional number una ("eight") and word for the animal idzu ("deer"). 
The Mixe or Mije ${ }^{12}$ of the southern part of Mexico had an extraordinary vocabulary for the calendar numbers but not for the calendar days (Lipp 1983, 203-205; Lipp 1991, 62-63; Duinmeijer 1997, 180-181). ${ }^{13}$

\section{[3.3] The Mixe 260-day calendar}

The names of the days in the calendar names are considered to be sacred and are thus reckoned by the K'iche' Maya in Momostenago of highland Guatemala as untranslatable. ${ }^{14}$ It is the sound of the day-name and the poetic sound play, paraonomasia, which are important, and not what they signify (Tedlock 1992, 107-108). For the Mixe it is rather an interpretation than a direct translation (Duinmeijer 1997, 182).

Ethnographic data from contemporary Maya cultures indicate that they conceive the numbers and the calendars to be deified. ${ }^{15}$ The association of the 13 numbers with deities of the 260-day calendar still survive among the Ixil (Maya). Not only the 13 numbers and 20 day-names are both seen as "sacred beings or deities who are worshiped and petitioned in prayer". The 13 numbers, associated with the day, are called "The Thirteen Kings". A calendar specialist in Nebaj told the ethnographer J. S. Lincoln: "The 20 day names are the Kings" (Lincoln 1942, 106-107). Contemporaneous Maya cultures, Ch'orti' and K'iche', regard the days as deities (Schultze Jena 1933; Goubaud Carrera 1935, 42; Girard 1966, 281; Tedlock 1992, 107). We know also from ethnographical investigations of Maya of the Highlands of Guatemala that the days were considered to be divine. La Farge and Byers and Lincoln report that the days were considered to be sacred living beings amongs the Jacaltec and Ixil (Lincoln 1942, 108; La Farge \& Byers 1931, 172-173). There was a deification of the 13 numbers, the 20-day deities and mountains in prayer. They were ".....worshipped and petitioned in prayer, together with the Holy Cross, God, Jesus Christ, the saints, the sun, the corn, and certain mountains and animals" (Lincoln 1942, 123-124). These calendar designations were accordingly not ordinary names but considered to have a particular religious value.

In many cases, the sources do not provide information about in what manner the individual was given his/her ordinary name, i.e. not calendar name. For the Mixtecs of Oaxaca, Mexico the conventional name was given to the child at the

[12] The word Mixe or Mije originates from Nahuatl. The Mixe apply the term Ayu:k, "word" or "language", which is etymologically connected to ha" $y$ yu:k, "people of the mountains" to identify themselves as a particular culture (Lipp 1983, 7; Lipp 1991, 1).

[13] The application of the thirteen calendar numbers is today restricted to villages of the lowland. Calendar numbers are close to ordinay numerals of the Zoque (Lipp 1983, 204; Duinmeijer 1997, 181-182). The Mixe calendar numbers might have become tabooed in everyday life and therefore only restriced to the 260-day calendar according to Søren Wichmann (Duinmeijer 1997, 181-182).

[14] For a discussion of the translations of the day names in Yucatec, Nahuatl and lowland Mixe cf. Wichmann (2000, 45-47).

[15] But also among other Mesoamerican peoples. For the Mixe cf. Lipp (1983). 


\begin{tabular}{|c|c|c|}
\hline Calendar numbers & Mixe numbers & Day names \\
\hline 1. Tu.m & tu'k & hukpi (root) \\
\hline 2. $\mathrm{mac}$ & meck & sa'a (wind) \\
\hline 3. tu:k & tukok or to.hk & how (palm) \\
\hline 4. makc & maktask & $\begin{array}{l}\text { hu:'n (hard, solid } \\
\text { resistant i.e. of tree or hb). }\end{array}$ \\
\hline 5. moks & mugo.sk & ca'an (serpent) \\
\hline 6. tuHt & tudu:k or tuhtti.k & ?uh (earth, world) \\
\hline 7. kuy & westu:k & koy (rabbit) \\
\hline 8. tu.gut & tuktu:k & na:n (deer) \\
\hline 9. ta:s & tastu:k & ni'in (water, river) \\
\hline 10. maHK & mahk & ho'o (?) \\
\hline 11. ki'in & mahktu'k & hai.m (fine white ashes) \\
\hline 12. ki'is & mahkmeck & ti'ic (tooth) \\
\hline 13. pagac & mahktikok or maktu.hk & kep (reed) \\
\hline 14. & & ka: (jaguar) \\
\hline 15. & & hu.ik (tobacco) \\
\hline 16. & & pa' \\
\hline 17. & & ?uhs (earthquake) \\
\hline 18. & & tahp (covered up, darkening) \\
\hline 19. & & miy (grass) \\
\hline 20. & & hugi'ñ (point [weaving]) \\
\hline
\end{tabular}

FIGURE 3: The Mixe 260-day calendar (si: tu'u "road of days" or si: may: y'g, "to divine" or "to count the days") (Lipp 1983, 203-205; Lipp 1991, 62-63).

age of seven by a religious specialist. But, how this name was determined has been not acknowledged (Smith 1973, 27-29).

The birth date of the 260-day calendar would decide the fate and the name of the newborn child. Consequently, the calendar sign determined the character, temperament and behaviour of the human being, e.g. the individual's identity. This phenomenon has been given the designation "tonalism", after tona, tonal or tonalli ("day"; "sun") in Nahuatl (López 1988). Tonalli constitute the I-macehual, "that which is granted to one, that which one deserves", to the individual according to the Aztecs (López 1988, 213-214). Fray Toribio de Motolinía, a member of the first delegations of Fransciscans who arrived in Mexico in 1524, describes this indigenous use of their 260-day calendar. It provided the child with a name on the seventh day after birth, which consituted either an animal or a plant. Various omens were also given (Motolinía 1971, 37). But Sahagún has observed that the calendar signs of the tonalamatl were either good or bad. Thus, there was not a 
fixed practice of naming the child on the seventh day after birth. If the sign was good the child was given a ritual bath and thereafter a name. If the sign was from a bad day the tonalpouhque discarded it and the ceremonial bath was postponed until a more suitable date. In this way the tonalpouhque manipulated the name and destiny, and thereby the character and identity, by improving the tonalli of the child: ipampa ic qujpatia in jtonal, ("For in that way they remedied his fate;") (Sahagún 1950-1982, 1957, IV: 30). The postponment was, however, restricted since the naming ritual had to take place within the 13-day period (trecena) the child was born (López 1988, 212). Moreover, since the predestination of the fatum after the day of birth was avoidable the significance of the calendar must accordingly not be overrated. The Aztecs also had a conception of human free will. Hence, men could either fullfill his destiny or destroy it (Sahagún 1950-1982, 1957, IV: 25).

In an intriguing passage in a book from the $16^{\text {th }}$ century, Fray Juan de Córdova gives various reasons why marriages were dissolved among the Zapotecs of Oaxaca, Mexico. One of these was a combination of the names of the couple that would cause misfortune to them or their offspring (Whitecotton 1977, 146). We can surmise that these names were from the 260-day calendar. Clearly, the names or identities - the name deciding the individual's character - played a significant role throughout the life of a human being. The tonalli is, however, probably more a faculty or an orientation that the human being can cultivate. In her experience with the modern K'iche'of Highland Guatemala, Barbara Tedlock argue that there is no dualism of good versus bad days but more complex prophecies (Tedlock 1992, 97-99).

The hombres-dios ("man-god") Toltec ruler Ce Acatl Topiltzin Quetzalcoatl ("One Reed Our Honourable Lord the Feathered Serpent") of the city Tula or Tollan ("Place of Reeds") in Hidalgo - located c. 80 kilometers north of Mexico City - represents a famous example of how a calendar name display a prophecy. The Toltec civilisation (c. 900 - c. $1200 \mathrm{AD}$ ) exercised a great influence on many later Mesoamerican cultures. The numerous mythological versions of his disappearance relate that Ce Acatl Topiltzin Quetzalcoatl some day would return according to his calendar name Ce Acatl (1 Reed). Many scholars has therefore hypothesised that the Aztec tlatoani (ruler) Motecuhzuma (II) believed that the later Spanish conquerer of the Aztec empire, Hernán Cortéz, was identical with the home coming Ce Acatl Topiltzin Quetzalcoatl because he arrived with his Spanish army in Mexico in 1519. This year correspond to the year Ce Acatl (1 Reed) of the Aztec 365-day and 52-year calendar, which got its name from the 260-day calendar. Ce Acatl represents the date the native prophets claimed that Ce Acatl Topiltzin Quetzalcoatl would return to Tenochtitlan (today Mexico City), the capital of the Aztec empire. 
This lead us to the phenomen, that day names of the 260-calendar name the individual year of the Mesoamerican 365-day calendar - which had an entirely different structure than the European 365-day calendar - and of the 52-year calendar. These day names are called Year Bearers.

\section{[4] THE NAMES AND IDENTITY OF THE YEAR BEARERS OF THE 365-DAY CALENDAR AND THE 52 -YEAR CALENDAR CYCLE}

The names of the 260-day calendar gave identity to other calendar or organised time systems.

I have already outlined the principle of the 260-day calendar. Let us briefly consider the temporal organisation and structure of the Mesoamerican 365-day calendar. This calendar, called xiuhitl in Nahuatl, is quite similar to the solar year but reflects instead a vague year. The actual length of the solar year is 365.2422 days. The vague year or the traditional Mesoamerican 365-day calendar, without leap days, was a quarter of a day or about six hours short of the solar year. The Mesoamerican 365-day calendar has eighteen time units (Sp. veintena) of 20 days each. The last and nineteenth veintena of the year contain only five days. Eighteen multiplied with twenty plus five amounts to 365 days.

Many of the Mesoamerican calendars consist of series of interlinking cycles. Scholars call the largest cyclical calendar in Mesoamerica the Calendar Round of 52 vague years. The Calendar Round combines the two distinct but interlocking calendars of respectively 260 and 365 days. A permutation of the 260-day and the 365-day cycle form a period of 52 vague years since it will take 18,980 days for a juxtaposed date of the 260-day and the 365-day calendar to be repeated in the Calendar Round. A Calendar Round consists therefore of a $52 \times 365$ day or a 73 x 260 -days cycle ( 94,900 days or 52 vague years) which can be compared to a European century for many indigenous people in Mesoamerica. ${ }^{16}$

In order to distinguish a 365-day calendar cycle from another in the 52-year calendar the people in Mesoamerica called every year after one of four particular days in the 260-day calendar for a "Year Bearer". ${ }^{17}$ The Year Bearer is a designation for the transition from one 365-day year to another 365-day year in the 52-year cycle or Calendar Round. Not more than four days from the 260-day calendar can mathematically be a Year Bearer. Since 260 and 365 have 5 as a common mathematical factor, only every fifth date of the 260-day calendar can coincide with a date of the 365-day calendar and vice versa. Each Year Bearer increases every year until it reaches the number thirteen. It will then re-begin at number one. After 52 years will the same Year Bearer with an identical coefficient, again occur (Thompson 1978, 128; Taube 1988, 181-182). In this manner the Year Bear-

[16] The longest time count of the Aztec was one hundred and four years (Huehuetiliztli), which the Nahua called a "century" (Sp. "siglo") according to Sahagún (Sahagún 1950-1982, 1957, V: 143).

[17] Landa call this for a "Dominical Day" (Tozzer 1941, 135-137). 
er of the 260-day calendar named and accordingly gave identity to every 365-day year in the 52-year calendar cycle.

[5] THE NAMES AND IDENTITY OF THE FOUR CARDINAL DIRECTIONS

Days of the 260-day calendar named and gave identity to quadripartite space or the four cardinal directions of the world.

We have seen that a Calendar Round was completed when the four Year Bearers of the 365-day calendar each had ruled 13 vague years. The Aztecs perceived the 52-year cycle as comprising four 13-year cycles in one great 52-year cycle. The Spanish ethnographer missionaries Fray Toribio de Benaventa Motolinía, Fray Diego Duran and Fray Bernardino de Sahagún writes that the 13 number cycle was repeated four times, generating 52 uniquely named years in a 52-year calendar cycle $(4 \times 13=52)$, which can be divided into four 13-year quarters. A round circle or calendar wheel of 52 years was divided into four parts. Every part, which represented a cardinal direction, contained thirteen years (Durán 1971, 389-391). The 52-year cycle subdivided into four periods of thirteen years contained the four Year Bearers:

(i) Tochtli (Rabbit)

(ii) Acatl (Reed)

(iii) Tecpatl (Flint)

(iv) Calli (House)

The year of the 52-year computation received its identity from the name (YB) of the 260-day calendar. The 52-year cycle began with Ce Tochtli (1 Rabbit) where the number one proceeded through thirteen four times (of the four Year Bearers) until the return of same date. The 52-year cycle was divided into the four quarters, tlapilli, began respectively with the date of the four Year Bearers, Ce Tochtli (1 Rabbit), Ce Acatl (1 Reed), Ce Tecpatl (1 Flint) and Ce Calli (1 House). Tochtli (Rabbit) was oriented toward the south, Acatl (Reed) to the east, Tecpatl (Flint) was associated with the north, and Calli (House) with the west. Each cardinal direction was ruled for thirteen years. ${ }^{18}$ Hence we get this spatial-temporal order of the 52-year calendar:

(i) Tochtli (Rabbit) of the south

[18] See Illustration of Plate 20 of a Calendar Wheel in book VII of The Florentine Codex of the four cardinal directions and the 52-year cycle (Sahagún 1950-1982, 1953, VII). A depiction of 52-year cycle with the four year-bearer signs associated with the four cardinal points is also illustrated in Codex Aubin (Read 1998, 93). 
(ii) Acatl (Reed) of the east

(iii) Tecpatl (Flint) of the north

(iv) Calli (House) of the west ${ }^{19}$

Space, the cardinal directions, and time accordingly received designations and thus identity from the 260-day calendar. These day-names of the 260-day calendar defined the quadripartite world in a spatial-temporal naming system.

[6] NAmes, Destinity And identity of THE AZteC Five World Ages We have seen that the calendar sign determined the destiny of an individual. A prophecy of the end of the world was also decided by the 260-day calendar.

A general agreement exists among scholars that the Aztecs had a notion of five world ages. The sequence of the five world ages ("Suns") in Aztec religion each has a distinctive set of characteristics and hence identities represented by names of the 260-day calendar. These were respectively terminated by a particular cataclysmic destruction and its inhabitants were either destroyed or transformed into another form (Elzey 1976, 117-118). The majority of the sources give each world age the names Nahui Ocelotl ("4 Jaguar"), Nahui Ehecatl ("4 Wind"), Nahui Quiahuitl ("4 Rain"), Nahui Atl ("4 Water") and Nahui Ollin ("4 Movement"). The following five world ages or world eras in a chronological or linear order can be identified as:

(i) Nahui Ocelotl (“4 Jaguar”).

(ii) Nahui Ehecatl (“4 Wind”).

(iii) Nahui Quiahuitl (“4 Rain”).

(iv) Nahui Atl (“4 Water").

(v) Nahui Ollin (“4 Movement”).

Each world age was named after a date in the 260-day cycle and associated with and presided over by a particular deity and a particular group of beings that were either exterminated or transformed into different kinds of beings in the first four creations. These were the dates on which the Suns or worlds were terminated. The world that we are now living in will end on the date Nahui Ollin

("4 Movement"). Ollin in this context refers to a world-devastating earthquake. Earthquakes are quite common in Central Mexico. Thus the names from the 260-day calendar of the Five Suns refer to the quality of the world age and the way its inhabitants will be demolished.

[19] Matlactli omome calli ("13 House"), the sign of the west, was the last sign of the four thirteen periods (Sahagún 1950-1982, 1953, VII: 21). 
[7] NAME, FREESOUL (TONALLI) AND IDENTITY

The termtonalli refers to a freesoul or a shadow without shape (Sp. "sombre") (López 1988, 204-205). ${ }^{20}$ George Foster writes that:

"The tonalli originally seems to have been a sort of soul, or at least a spiritual essence, because should the individual lose his tonalli he sickened, and if it were not returned, he died" (Foster 1944, 94-95).

This phenomenon associated with the traditional 260-day calendar has been recognised among the contemporary K'iche' of Highland Guatemala. Every day has its face, identity or character of the 260-day calendar, rajilábal k'ij, which influence events. A person's good fortune or destiny is named uwäch uk'ij ("the face of one's day" or "one's character", i.e. the personality or character of a human being). Any day imparts the uwäch uk'ij to a child born on that day (Tedlock 1992, 110). It is decided by the birthday in the 260-day calendar. Uwäch uk'ij can leave the body when the individual dreams and meets other people's uwäch uk'ij (Tedlock 1992, 315). It represents therefore a tonalli or a free soul.

Hernando Ruiz de Alarcón is the first known ethnographer missionary - if we do not count the dictionary by Molina - who outlines this phenomenon in Treatise on the Heathen Superstitions that today live among the Indians native to this New Spain (1629) (Andrews and Hassig in Alarcón 1984, 45; 313, note 6). Ruiz de Alarcón, describes the tonalli as a substance, a freesoul that lived in the body but could leave it. But where in the body of the human being was the tonalli located? Sahagún relates that the nahualli ${ }^{21}$ could be passified in his/her human form by being skalped. His reputation and day sign (tonalli) became thus destroyed (Sahagún 1950-1982, 1957, IV: 102). This represented a weakness for the supernatural nahualli since his/her extranormal power was in the hair (tonalli). The nahualli could only save him or herself by taking an object from the person who had captured him or her (Sahagún 1950-1982, 1957, IV: 43).

The freesoul and name ideology had medical implications. The patient was diagnosed by the Nahua ticitl ("doctor") as one who lacks a tonalli or destiny (Sp. "fortuna") and accordingly a name (Alarcón 1984, 161). He or she will not recover until his or her tonalli has reappeared (oquicauh itonal, "his/her tonal has abandoned him/her") (Hassig and Andrews in Alarcón 1984, 361, note 9). There were (also female) tetonaltique (tetonaltih, "one who provides a person a tonal") or tet-

[20] López Austin defines the lexem tonal or tonalli as:

' $a$. Solar irradiation; $b$. solar warmth; $c$. summer; $d$. day; e. day sign, $f$. divine influence; $g$. a person's destiny due to the day of his birth; $h$. animistic entity that can either spontaneously or accidentally leave a person and that relates him to the rest of the universe; $i$. something that is destined or belongs to a certain person. It was also called TOTONAL, using the possessive of the first person plural' (López 1988, 297).

[21] A nahualli refer in this context to a religious specialist who can transform him or herself to an animal or a natural phenomenon. 
onalmacanih ("tonal-givers"), i.e. specialised doctors who located the lost tonal of the patient (Hassig and Andrews in Alarcón 1984, 247; 380). They could in various healing-ceremonies bring the tonalli, and accordingly the name, back to the patient (Alarcón 1984, 161).

[8] NAMING PRACTICES AND IDENTITY OF HUMANS, Divine BEINGS AND SPATIO-TEMPORAL SYSTEMS

Naming practices of the 260-day calendar gave identity to humans, deities, world ages, the 365-calendar, the 52-year calendar and quadripartite space of the world, i.e. the cardinal directions of the Mesoamerican spatial-temporal system. The phenomenon of naming human beings and deities has been categorised as "tonalism". Moreover, the tonalli-concept constitutes a predestined fate and a freesoul (a definite shape that can be lost, which also implies could happen to the name) connected to a day-sign of the 260-day calendar. The day-name is in this manner associated with the character, personality, destiny and accordingly identity of a being or phenomenon.

\section{REFERENCES}

Alarcón, H. Ruiz de. 1984. Treatise on the heathen superstitions that today live among the Indians native to this New Spain, 1629. In The Civilization of the American Indian series, vol. 164, Norman: University of Oklahoma Press. Translated and edited by J. Richard Andrews and Ross Hassig.

Boone, E.H. 2000. Stories in Red and Black: Pictorial Histories of the Aztecs and Mixtecs. USA: University of Texas Press.

Bricker, V.R. \& H.M. Miram. 2002. An Encounter of Two Worlds. The Book of Chilam Balam of Kaua. New Orleans: Middle American Research Institute. Tulane University.

Broda, J. 1969. The Mexican Calendar as Compared to other Mesoamerican Systems. In Acta Ethnologica et Linguistica, vol. 15, Wien: Inst.f. Völkerkunde d. Univ. Wien.

Colas, P.R. 2004. Sinn und Bedeutung klassicher Maya-Personnamen. Typologische Analyse von Anthroponymphrasenin en Hieroglpheninschriften der klassischen Maya-Kultur als Beitrag zur allgemeiene Onomastik. InauguralDissertation zur Erlangung der Doktorwürde der Philosophischen Fakultät der Rheinischen Friedrich-Wilhelms Universität zu Bonn. In Acta Mesoamerican, vol. 15, Germany: Verlag Anton Saurwein.

Dahlgren, B. 1954. La Mixteca: Su cultura e historia prehispánicas. Mexico City: Universidad Nacional Autónoma de México. 
Duinmeijer, B. 1997. The Mesoamerican Calendar of the Mixes, Oaxaca, Mexico. Yumtzilob 9. 173-205. No. 2.

Durán, F.D. 1971. Book of the Gods and Rites and the Ancient Calendar. Norman: University of Oklahoma Press.

Elzey, W. 1976. The Nahua Myth of the Suns. History and Cosmology in PreHispanic Mexican Religions. NUMEN. International Review for the History of Religions 23. 114-135.

Foster, G. 1944. Nagualism in México and Guatemala. Acta Americana 2. 85-103.

Girard, R. 1960. L'Ésotérisme du Popol-Vuh. Le livre sacré et des mythes de l'antiquité américaine. Livres héroïques et historiques des Maya-Quiché. Paris: Librairie D'Amerique et D'Orient Adrien-Maisonneuve. Traduit de l'original espagnol par R. P. Tastevin.

Girard, R. 1962. Los maya eternos. Mexico: Antigua Libreria Robredo.

Girard, R. 1966. Los mayas: su civilization-su historia sus vinculaciones continentals. Mexico: Libro Mex. Editores.

Goubaud Carrera, A. 1935. El "Guajxaquíp Báts" - Ceremonia calendárica indígena. Anales de la Sociedad de Geografía e Historia de Guatemala 12. 39-52.

Krogseth, O. 1992. Identitet. In Jan-Olav Henriksen and Otto Krogseth (ed.) in collaboration with Pål Ketil Botvar and Ingvil T. Plesner: Pluralisme og identitet. Kulturanalytiske perspektiver pånordiske nasjonalkirker i møte med religiøs og moralsk pluralisme, 85-184. Gyldendal Akademisk.

La Farge, O. \& D.S. Byers. 1931. The Year Bearer's People. In Tulane university of louisiana, middle american research series, vol. 3, New Orleans: Tulane University.

Larsen, H. 1936. The 260-Day Period as Related to the Agricultural Life of the Ancient Indian. In Ethnos, vol. 1, 9-12.

Lincoln, J.S. 1942. The Maya Calendar and the Ixil of Guatemala. Contributions to American Anthropology and History 38. 99-128.

Lipp, F.J. 1983. The Mije Calendarical System. Concepts and Behavior. In New school for social research, New York. Doctoral dissertation.

Lipp, F.J. 1991. The Mixe of Oaxaca. Religion, Ritual and Healing. Austin: University of Texas Press. 
Lockhart, J. 1992. The Nahuas After the Conquest. A Social and Cultural History of the Indians of Central Mexico, Sixteenth through Eighteenth Centuries. Stanford, California: Stanford University Press.

López, A.A. 1988. The Human Body and Ideology: Concepts of the Ancient Nahuas. Salt Lake City: University of Utah Press. Transl. by Thelma Ortiz de Montellano and Bernhard Ortiz de Montellano. 2 vols.

Milbrath, S. 1999. Star Gods of the Maya. Astronomy in Art, Folklore, and Calendars. Austin: University of Texas Press. (The Linda Schele Series in Maya and PreColumbian Studies.).

Motolinía, F. de Benavente. 1971. Memoriales o libro de las cosas de la Nueva España y de los naturales de ella. Mexico City: Universidad Nacional Autónoma de México.

Read, K.A. 1998. Time and sacrifice in the aztec cosmos. Bloomington: Indiana University Press.

Roys, R. 1940. Personal names of the Maya of Yucatán. In Contributions to American Anthropology and History, vol. 6 (31), 31-48. Washington, DC: Carnegie Institution of Washington. Publication, 523.

Sahagún, F.B. de. 1950-1982. General History of the Things of New Spain: Florentine Codex. Santa Fe: School of American Research and University of Utah. Charles E. Dibble and Arthur J. V. Anderson, trans. 13 vols.

Schultze Jena, L. 1933. Leben, Glaube und Sprache der Quiché von Guatemala. Gustav Fischer Jena.

Smith, M.E. 1973. Picture Writing from Ancient Southern Mexico. Mixtec Place Signs and Maps. Norman, USA: University of Oklahoma Press.

Taube, K.A. 1988. The Ancient Yucatec New Year Festival: The Liminal period in Maya ritual and cosmology. Yale University. Diss.

Tedlock, B. 1992. Time and the Highland Maya. Albuquerque: University New Mexico Press.

Terraciano, K. 2001. The Mixtecs of Colonial Oaxaca. Nudzahui History, Sixteenth Through Eighteenth Centuries. Stanford, California. USA: Stanford University Press.

Thompson, Sir J.E.S. 1930. Ethnology of the Mayas of Southern and Central British Hounduras. In Anthropological series, vol. 17, No. 2, Chicago: Field Museum. (Field Museum of Natural History, Publication 274.). 
Thompson, Sir J.E.S. 1978. Maya Hieroglyphic Writing: An Introduction. Norman: University of Oklahoma Press.

Tozzer, A.M. 1941. Landa's relacion de las cosas de Yucatán. In Papers of the peabody museum of archaeology and ethnology, harvard university, vol. 18, Cambridge, Mass.: The Museum.

Whitecotton, J.W. 1977. The Zapotecs: Princes, Priests, and Peasants. In The Civilization of the American Indian Series, Norman, USA: University of Oklahoma Press.

Wichmann, S. 2000. Mayaernes skrift - Introduktion og håndbog. København. Under forberedelse. Privat kopi.

AUTHOR CONTACT INFORMATION

Lars Kirkhusmo Pharo

Moses Mesoamerican Archive

Harvard University

11 Divinity Avenue

Cambridge, MA 02138

USA

l.k.pharo@gmail.com 